\title{
EFFECTS OF FOOD QUALITY, SERVICE QUALITY, PRICE, ENVIRONMENT, AND LOCATION TOWARDS CUSTOMER LOYALTY OF INDONESIA'S LOCAL FAST FOOD INDUSTRY
}

\author{
Indryati Sunaryo $^{1 *}$, Ilham Reza Prasetyo ${ }^{1}$, Pamoedji Hardjomidjojo ${ }^{1}$, Luthfi \\ Nurdianchah $^{2}$ \\ ${ }^{1}$ Industrial Management Research Group, Faculty of Industrial Technology, Institut Teknologi Bandung, \\ Labtek III Gedung Mattias Aroef, Institut Teknologi Bandung, Jl. Ganeca No. 10, 40132 \\ ${ }^{2}$ Industrial Engineering \& Management Program, Faculty of Industrial Technology, Institut Teknologi Bandung, \\ Labtek III Gedung Mattias Aroef, Institut Teknologi Bandung, Jl. Ganeca No. 10, 40132
}

(Received: November 4, 2019/Accepted: November 21, 2019)

\begin{abstract}
This study aims to measure and analyze the effect of several restaurant-related quality attributes toward customer loyalty with a mediating effect from customer satisfaction in the local fast-food industry in Indonesia. The nature of local fast-food industry is different compared to its global counterpart, so a new perspective has to be taken into account. Based on literature review of previous studies, the quality attributes that are selected for this study are food quality, service quality, environment, price, and location. Data in this study were collected from the responses of 461 participants and analyzed using Structural Equation Model (SEM). The SEM result shows that only price and location significantly affect customer loyalty through customer satisfaction. When customer satisfaction is removed and restaurant-related quality attributes is directly tested towards customer loyalty, only price and food quality significantly affect customer loyalty. Both with and without mediating effect from customer satisfaction, price keeps influencing customer loyalty. This result is against the majority of fast-food customer loyalty studies which usually emphasize on food or service quality as the main factor that influences customer loyalty and customer satisfaction.
\end{abstract}

Keywords: Fast-food industry; customer loyalty; customer satisfaction; food quality

\section{Introduction}

Initiated in early 2000's, local fast-food industry in Indonesia keeps growing in terms of number of firms and types of food offered. The emergence of local fastfood industry in Indonesia is rather insulated from the competition given by the global fast food industry because of difference in the market-segment targeted. Local fast-food industry in Indonesia targets significantly lower price bracket than their global chain counterpart. Therefore, these two industries do not necessarily compete with each other but rather complement in terms of product price.

Firms in the local fast-food industry face a more considerable challenge intra-industry with each other, through customer loyalty. To keep prices down, firms in the local fast food industry usually provide minimal

*Correspondence Author.

E-mail: indryati.itb@gmail.com service and physical environment. Low product prices combined with lack-of-variation in products among local fast food firms create a low switching cost environment that increase the competition intensity in local fast food industry (Lee, et al., 2001; Doganoglu, 2010). The advantages created by the switching cost such as psychological barrier for customers and enhances motivation for establishing relationship (Sahagun \& Vasquez-Parraga, 2014) are simply non-existent. Therefore, keeping customers loyal under this lowswitching cost environment is key in this industry.

Customer loyalty is important because it will lead to numerous benefits for the firm. One of the benefits led by customer loyalty is customer retention, a key in achieving long run profitability (Terblanche, 2009; Alshurideh, 2016). Furthermore, it is estimated that almost in all industries, firms have to spend about three to five times more to attract new customers than to retain existing ones (Mason, et al., 2016). Other than long run profitability, customer retention can also bring marketing 
cost lower, more opportunity for product cross selling, and higher positive word of mouth (Terblanche, 2009). Again, customer retention can only be achieved if customers are loyal.A study is needed to find out more about customer loyalty in a low switching cost environment, especially in fast-food industries. Fast-food customers see an offering as a package that can fulfil their needs (Haghighi et al., 2012). In fast food industries, customers see the offering as a package consist of several components such as the food, the service and the facilities. Then, they will make decision based on attributes of the package. By understanding these attributes, firms can be more focused in its effort to meet customers' expectation and hinder customer defection to happen.

Many studies argue that satisfaction is an antecedent of loyalty (Parasuraman et al., 1988; Cronin and Taylor, 1992; Haghighi, et al., 2012; Etemad-Sajadi \& Rizzuto, 2013; Liu et al., 2016). Therefore, increasing satisfaction will generate increasing customer loyalty. Previous studies stated that customer satisfaction in fastfood industry is influenced by food quality (Namkung \& Jang, 2007; Ryu, et al., 2010; Mathe-Souleka, et al., 2015; Namin, 2017), service quality, environment, atmosphere, physical setting and location (Parasuraman et al., 1988; Stevens, 1995; Qin, et al., 2010; Haghighi et al., 2012; Ryu, et al., 2012; Etemad-Sajadi \& Rizzuto, 2013; Liu, 2016; Alhelalat, 2017). Product price also plays a significant role in influencing customer satisfaction (Kim, et al., 2006; Jin, et al., 2012; Voon, 2017). Location also influences customer satisfaction because it affects customer's perception on time and effort needed to acquire the product/service. (Soriano, 2002; Heung, 2002; Tzeng, et al., 2002; Hyun, 2010; Haghighi, 2012).

Unfortunately, most of these studies are performed in the context of fast-food in the United States, Europe, or China which are quite different with local fastfood in Indonesia. Unlike in those countries, local fastfood firms in Indonesia mostly offers minimum service and physical environment. A fast-food shop usually only consists of a food stand and a server. Customers usually take away their orders because most of the time there is no option to dine-in. These fundamental differences provide a research gap which leads to the question of whether previous research results could be applied effectively by firms in the local market. This question becomes the very background of this study. Thus, this study proposed and empirically tested a comprehensive model using several quality-attributes obtained from previous study, and measured their subsequent relationship with customer loyalty through customer satisfaction.

\section{Research Methodology \\ A. Development of Conceptual Model}

Customer satisfaction used to be the only focus in consumer study. Parasuraman, et al. (1988) developed the widely-regarded SERVQUAL instruments and argued that cultivating service quality to satisfy customer is very important. Reichheld (1996) on the other hand, coined the term "the satisfaction trap" that argued merely satisfying customer is not enough. Measuring satisfaction is important, but to consider it as the key of business is simply misleading as he claimed that $65 \%$ to $85 \%$ of satisfied customer would still defect. Oliver (1999) then supported this theory by stating that, while customer loyalty and customer satisfaction are undoubtedly related, these two constructs are asymmetric. Customers who are loyal mostly also satisfied, but customers who are satisfied are not universally loyal. To get customer loyalty, customer satisfaction has to be nurtured carefully.

There have been numerous studies regarding determinants of customer satisfaction and customer loyalty in the fast-food industry. But, as previously explained, local fast-food industry in Indonesia is practically different than its global-chain counterpart. Consequently, a new perspective has to be taken into account to study customer satisfaction and customer loyalty in this industry.

The first factor that can be considered to be affecting customer satisfaction is food quality. It has always been considered to be a fundamental component of restaurant experience but often got overlooked because of the prominence of service quality theory in the 90's and early 2000's (Namkung \& Jang, 2007). Still, many studies that tried to find the most important aspect in defining customer satisfaction of food industry found the importance of food quality in fast-food industry (Ryu, et al., 2010; Mathe-Souleka, et al., 2015; Namin, 2017). Especially considering the quickness of transaction and the modest food stall commonly used in this industry which render food quality as the most important. Therefore, understandably food quality must be prioritized in determining customer satisfaction (Canny, 2014). Studies by Grunert (2005) and Rijswijk and Frewer (2008) even put greater emphasize on food quality as the determinant of customer satisfaction as they only considered food quality without any attention to service quality in their studies.

Service quality in the other hand, has always been the very consideration in measuring customer loyalty and satisfaction in the restaurant industry. Parasuraman, et al. (1988) developed SERVQUAL instruments to empashize the importance of service quality. Later, Stevens, et al. (1995), also argued that customer satisfaction was more influenced by its service quality than any other attributes. This argument was also supported recently by Liu, et al. (2016) and Alhelalat, et al. (2017) who proposed that service quality defined the customer satisfaction the most. Qin, et al. (2010) 
improved the SERVPERF instrument to better explain factors affecting customer satisfaction and found that reliability, recovery, appearance, and responsiveness were a significant dimensions of service quality. Gonzales, et al. (2007) and Andaleeb \& Conway (2006) also concluded that service quality is the most important in determining customer satisfaction.

Environment is another factor to be considered in determining customer satisfaction. Han \& Ryu (2009) investigated the effect of physical environment factors such as layout and comforts towards customer satisfaction and loyalty and found that environment factor proven to have a significant effect. Wu \& Liang (2009) revealed that the quality of service encounter which include atmosphere and environment is a significant predictor of restaurant customer satisfaction and experience. Other studies also concluded that environment is one of the factors that has a significant effect on customer satisfaction (Haghighi, 2012; Jin, et al., 2012; Canny, 2014).

Price can also be considered to be one of the factors affecting customer satisfaction. Law, et al. (2008) explained that price was one of the attributes that can change customer's attitude. Jin, et al. (2012) showed that perception of price fairness influenced customer satisfaction significantly. Same conclusion was also reached by Han \& Ryu (2009) who investigated the effects of perception of price and physical environment towards customer satisfaction. Kim, et al. (2006) also found that price was important in affecting customer's trust. Voon (2017) also came to the same conclusion regarding the role of price towards customer satisfaction from the perspective of youth customers.

Lastly, location is another factor that is commonly used to determine customer satisfaction. Soriano (2002) explained that customer who felt satisfy expected that the location of restaurant was still in a comfortable range. Heung (2002) also stated that location could also be used to measure competitiveness of a restaurant. Few other studies also used location as a determinant factor of customer satisfaction and found that this factor significantly affect satisfaction (Tzeng, et al., 2002; Hyun, 2010; Haghighi, 2012).

As previously explained, there have been many studies regarding customer satisfaction in the fast-food industry. From looking at those studies, it can be concluded that the most common factors used to determine customer satisfaction are food quality, service quality, environment, price, and location. Subsequently, there are numerous studies that confirm customer satisfaction to have a significant effect towards customer loyalty. Therefore, the hypotheses to be tested on this study are as follows:

H1: Food Quality (FQ) positively influences customer satisfaction.
H2: Service Quality (SQ) positively influences customer satisfaction.

H3: Environment (EV) positively influences customer satisfaction.

H4: Price (PC) positively influences customer satisfaction.

H5: Location (LC) positively influences customer satisfaction.

H6: Customer satisfaction (CS) positively influences customer loyalty (CL).

Thus, the model developed in this study is shown on Figure 1.

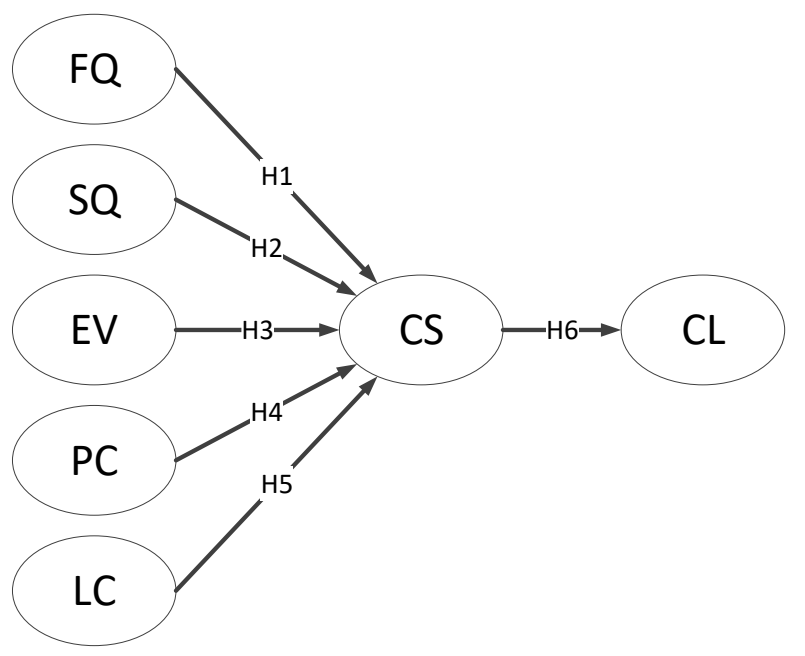

Figure 1. Conceptual Model being Developed

\section{B. Data Collection and Data Analysis}

These 7 constructs are operationalized into 46 indicators. The operationalization process is undertaken referring to relevant previous studies about customer loyalty, customer satisfaction, and quality. These indicators and their sources are shown in Table 1.

A questionnaire is developed as the instrument to gather data to investigate hypotheses that have been formulated before. The questionnaire is developed based on the conceptual model. Previous studies by Qin, et al. (2010), Haghighi, et al. (2012), Jin, et al. (2012), Canny (2014), and Namin (2017) become the basis of the questionnaire on this study. These studies are chosen because they provide valid and reliable questionnaires on their studies. Variables that were used on those studies were also originated and compiled from numerous studies regarding customer loyalty and satisfaction in the fastfood industry.

The result of this process is a questionnaire with 35 items using rating scale from $0-100$. The reasoning of using rating scale is to improve quality of response as the respondent have higher range of choice to answer the questions. 

Convenience sampling was used as the sampling method. Questionnaires were distributed in collaboration with a local fast-food outlet in Bandung to ensure that respondents who took part in the survey were actual customers of local fast-food industry. Data collection yielded responses from 461 participants that are used as the empirical data of this study.

Table 1. Quality Attributes, Indicators, and Sources of Indicators

\begin{tabular}{|c|c|c|c|c|}
\hline No & $\begin{array}{c}\text { Quality } \\
\text { Attributes/Construct }\end{array}$ & Code & Manifest Variables/Indicators & Sources \\
\hline 1 & Food Quality & FQ & $\begin{array}{l}\text { Food Presentation, Temperature, } \\
\text { Freshness, Flavour, Variety }\end{array}$ & $\begin{array}{l}\text { Qin, et al. (2010), Haghighi, et al. (2012), } \\
\text { Jin, et al. (2012), Canny (2014), and } \\
\text { Namin (2017) }\end{array}$ \\
\hline 2 & Service Quality & SQ & $\begin{array}{l}\text { Staff Appearance, Equipment } \\
\text { Cleanliness, Responsiveness, } \\
\text { Assurances, Reliability, Speed of } \\
\text { Service, Empathy, Recoverability, } \\
\text { Operating Hours }\end{array}$ & $\begin{array}{l}\text { Qin, et al. (2010), Haghighi, et al. (2012), } \\
\text { and Namin (2017) }\end{array}$ \\
\hline 3 & Environment & $\mathrm{E}$ & $\begin{array}{l}\text { Cleanliness, Stall Design, Stall } \\
\text { Colors, Comfort, Waiting } \\
\text { Equipments }\end{array}$ & $\begin{array}{l}\text { Haghighi, et al. (2012), Jin, et al. (2012), } \\
\text { Canny (2014), and Namin (2017) }\end{array}$ \\
\hline 4 & Price & $\mathrm{P}$ & $\begin{array}{l}\text { Competitive Price, Price-quality } \\
\text { trade-off, Price-service trade-off }\end{array}$ & $\begin{array}{l}\text { Qin, et al. (2010), Jin, et al. (2012), and } \\
\text { Namin (2017) }\end{array}$ \\
\hline 5 & Location & $\mathrm{L}$ & $\begin{array}{l}\text { Parking area, strategic location, } \\
\text { access, security }\end{array}$ & Haghighi, et al. (2012) and Namin (2017) \\
\hline 6 & Customer Satisfaction & CS & $\begin{array}{l}\text { Performance satisfaction, } \\
\text { experience, needs fulfillment, } \\
\text { expectation, overall satisfaction }\end{array}$ & $\begin{array}{l}\text { Haghighi, et al. (2012), Jin, et al. (2012), } \\
\text { and Namin (2017) }\end{array}$ \\
\hline 7 & Customer Loyalty & CL & $\begin{array}{l}\text { Intention, recommendation, } \\
\text { positive review to others, } \\
\text { alternative choice }\end{array}$ & $\begin{array}{l}\text { Qin, et al. (2010), Haghighi, et al. (2012), } \\
\text { Jin, et al. (2012), Canny (2014) }\end{array}$ \\
\hline
\end{tabular}

Table 2. Result of Reliability Test

\begin{tabular}{clcc}
\hline No & Constructs & Cronbach Alpha Value & Conclusion \\
\hline 1 & Food Quality & 0.950 & Reliable \\
2 & Service Quality & 0.928 & Reliable \\
3 & Environment & 0.915 & Reliable \\
4 & Price & 0.953 & Reliable \\
5 & Location & 0.853 & Reliable \\
\hline
\end{tabular}

This number of responses is sufficient to be analyzed using Weighted Least Square (WLS) Estimation on Structural Equation Modeling (SEM) as it is more than 10 times the number of questions on the questionnaire (Wijanto, 2008).

Data were analyzed using Structural Equation Modelling (SEM). SEM is chosen because it is a strong method to analyze relationship between dependent and independent variables and it is commonly used in the customer loyalty-satisfaction-quality study. LISREL 8.72 was used for the data analysis process.

\section{Result and Discussion}

Data is analyzed using Structural Equation Modeling (SEM) to examine the relationship between customer loyalty, customer satisfaction, and qualityattributes constructs. However, before being processed using SEM, the variables being studied were undergone test for normality, validity and reliability first.

Normality is tested in 2 staged. The first stage is the univariate normality test. Every manifest variables that are used on this study fail the normality test as the Pvalue of both skewness and kurtosis of them are less than 0.05. Dataset are then transformed using normal score 
transformation feature in LISREL 8.72. After the transformation, every variables in the dataset are declared to pass the univariate normality test. Multivariate normality is tested on the second stage. The result shows that the dataset does not pass the multivariate normality test, even after transformation which affects the estimation process of SEM.

Validity test was checked using 2 criteria. These criteria were standardized loading factor $(\lambda)$ and $t$-value. The variables are valid if the standardized loading factor exceed 0.50 (Hair, et al., 2014) and the t-value is larger than 1.96 (significance level/ $\alpha$ of 5\%) (Wijanto, 2008). The validity test result shows that every variable used in this study is valid as there is no t-value of the variables being below 9.69 and all of the value of the standardized loading factor exceed 0.5 with the lowest value being 0.61. The reliability test was checked using Cronbach alpha as the criteria. The variables were considered to be reliable if the Cronbach alpha value exceed 0.6. The reliability test result as shown in Table 2 reveals that every variable is reliable to its construct with the Cronbach alpha value ranging from 0.853 to 0.953 .

After the validity and the reliability of the data have been established, one of the most important considerations in using SEM is the fitness of the structural model. In this regard, several Goodness of Fit (GOF) criteria are chosen to be performed using LISREL:

1. Statistics Chi-square $\left(\chi^{2}\right)-P$

2. Non-centrality Parameter (NCP) - Interval

3. Root Mean Square Error of Approximation (RMSEA) - P (Close Fit)

4. Expected Cross Validation Index (EVCI)

5. Akaike Information Criterion (AIC)

6. Consistent Akaike Information Criterion

7. Normed Fit Index (NFI)

8. Tucker Lewis Index (TLI)

9. Comparative Fit Index (CFI)

10. Incremental Fit Index (IFI)

11. Relative Fit Index (RFI)

12. Critical "N" $(\mathrm{CN})$
13. Root Mean Square Residuant (RMR)

14. Goodness-of-Fit Index (GFI)

15. Adjusted Goodness of Fit Index (AGFI)

The 7 constructs of quality attributes that are used on this study are then checked based on the aforementioned criteria. The summary of the GOF test is shown on table 3 .

Hair, et al. (2014) explained that if the majority of the criteria is fulfilled, then it can be concluded that the model has a good fit and is good enough to be used in SEM. From table 2, it can be concluded that the model passes the majority of the GOF criteria. Every construct has between 12 to 15 criterias that are at least marginal fit which means that the model is fit.

After Goodness of Fit of the model is proven to be sufficient, the hypothesis previously formulated are tested. Estimation is performed using Weighted Least Square (WLS) rather than Maximum Likelihood (ML) because the data used in this study fail the normality test. The data could still be processed using WLS Estimation provided the number of samples is large enough (Wijanto, 2008). Anticipating this, more than 670 responses were initially recorded with 461 responses finally being used which satisfy the minimum requirement to process the data using WLS estimation.

SEM yields path coefficient value and t-value for every hypothesis being tested. Coefficient path value explains how much influence a variable has while t-value explains whether the hypothesis is accepted or rejected. The SEM result is shown on table 4.

The $\alpha$ value of 0.05 is chosen in this study. Therefore, to be accepted, each hypothesis must have tvalue above 1.96 or below -1.96 . According to the SEM result, only 3 out of 6 hypotheses are accepted. Only relationship between Price (PC) to Customer Satisfaction (CS), Location (LC) to Customer Satisfaction (CS), and Customer Satisfaction (CS) to Customer Loyalty (CL) that are proven to be significant. The rest of the hypotheses are rejected. Figure 3 shows the model after hypothesis testing.

Table 3. Summary of Goodness of Fit from 15 Criterias

\begin{tabular}{lcccccc}
\hline No & Constructs Code & Close Fit & Good Fit & Marginal Fit & Not a Good Fit & Conclusion \\
\hline 1 & FQ & 0 & 10 & 3 & 2 & Model Fit \\
\hline 2 & SQ & 1 & 9 & 2 & 3 & Model Fit \\
\hline 3 & E & 0 & 9 & 4 & 2 & Model Fit \\
\hline 4 & P & 0 & 15 & 0 & 0 & Model Fit \\
\hline 5 & L & 0 & 11 & 3 & 1 & Model Fit \\
\hline 6 & CS & 1 & 14 & 0 & 0 & Model Fit \\
\hline 7 & CL & 0 & 13 & 1 & 1 & Model Fit \\
\hline
\end{tabular}


Table 4. SEM Result for Hypotheses Testing

\begin{tabular}{cccc}
\hline No & Path (Hypothesis) & Path CoefficientValue & t-value \\
\hline 1 & FQ $\rightarrow$ CS (H1) & 0.023 & 0.42 \\
2 & SQ $\rightarrow$ CS (H2) & -0.049 & -1.01 \\
3 & EV $\rightarrow$ CS (H3) & -0.032 & -0.64 \\
4 & PC $\rightarrow$ CS (H4) & 0.130 & 2.22 \\
5 & LC $\rightarrow$ CS (H5) & 0.071 & 2.29 \\
6 & CS $\rightarrow$ CL (H6) & 0.610 & 5.32 \\
\hline
\end{tabular}

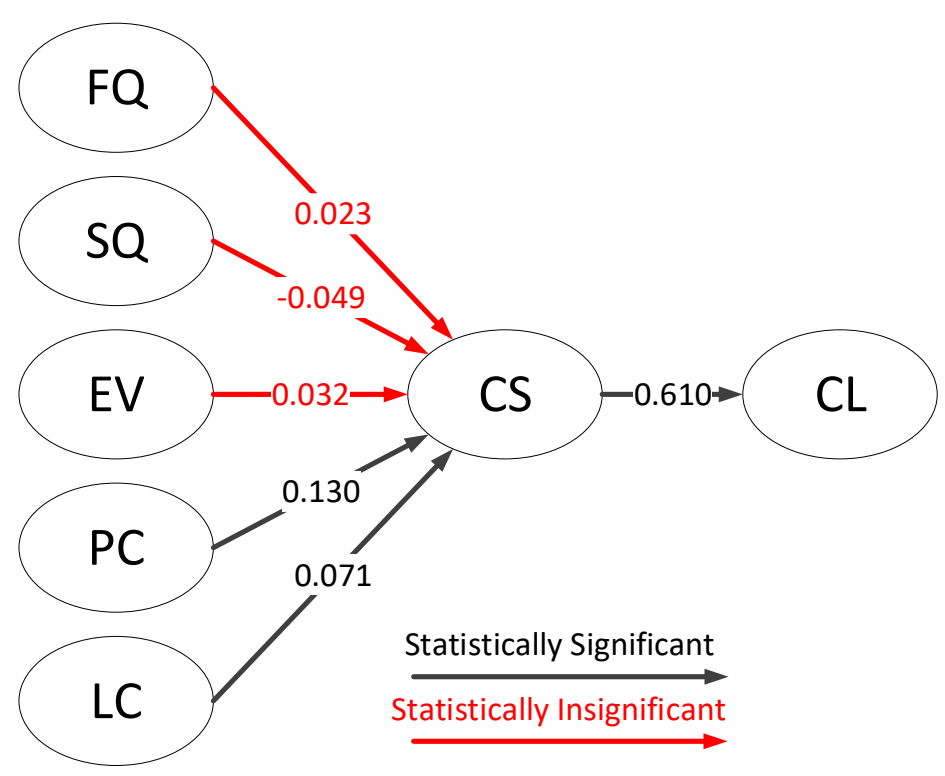

Figure 2. Hypothesis Testing Result

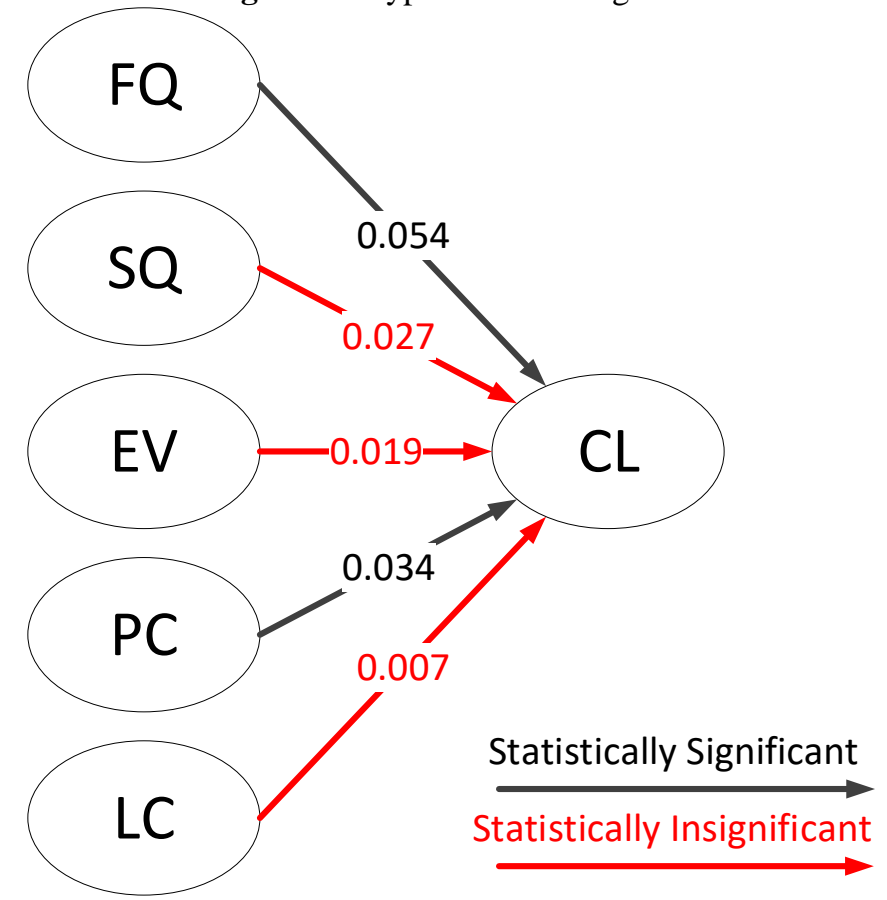

Figure 3. Direct Testing Result 
Table 5. SEM Result for Direct Testing

\begin{tabular}{cccc}
\hline No & Path & Path Coefficient Value & t-value \\
\hline 1 & FQ $\rightarrow$ CL & 0.054 & 1.39 \\
2 & SQ $\rightarrow$ CL & 0.027 & 4.43 \\
3 & EV $\rightarrow$ CL & 0.019 & 2.91 \\
4 & PC $\rightarrow$ CL & 0.034 & 1.94 \\
5 & LC $\rightarrow$ CL & 0.007 & 0.86 \\
\hline
\end{tabular}

Referring to studies regarding customer loyalty, customer satisfaction mostly plays a part in mediating the effect of product/service quality towards customer loyalty. That being said, to complement the result of this study, direct testing of quality attributes towards customer loyalty will also be performed to investigate both the possibility that quality attributes have a direct effect to customer loyalty and the mediating role of customer satisfaction in determining customer loyalty. The SEM result of this direct testing is shown on table 4.

Using the same $\alpha$ value of 0.05 as the previous hypothesis testing, only food quality and price that have a positive influence towards customer loyalty. Figure 3 shows the model and the result of hypothesis testing.

The difference of result between direct testing and the previous hypothesis testing shows that customer satisfaction has a mediating effect on quality attributes used to determine customer loyalty.

Unexpectedly, using the original model, only price and location affect customer loyalty with a mediating effect from customer satisfaction. Food quality, service quality, and environment, through customer satisfaction, are proven to have no significant effect towards customer loyalty.

Service quality and environment, although supported by numerous studies to significantly affect customer loyalty or customer satisfaction (Parasuraman et al., 1988; Stevens, 1995; Qin, et al., 2010; Haghighi et al., 2012; Ryu, et al., 2012; Etemad-Sajadi \& Rizzuto, 2013; Liu, 2016; Alhelalat, 2017), were expected to have little influence after taking into account the nature of local fast-food industry business in Indonesia. Earlier, it has been established that local fast-food shop in Indonesia is different with fast-food shop that became the object of most studies regarding customer satisfaction and customer loyalty. Findings on this study confirm that quickness of service and minimal physical environment provided by almost all of the fast-food shop render service quality and environment irrelevant for most customers to build satisfaction.

Food quality, however, was expected to have a significant effect towards customer loyalty through customer satisfaction. It was thought that, in the absence of service quality and physical environment, customers would expect food to be the important part of fast-food offerings. But the findings of this study prove it not to be so. Fast-food customers seems indifferent towards fast food quality. This finding is also against the conclusion of majority of the studies investigating factors of customer satisfaction and customer (Namkung \& Jang, 2007; Ryu, et al., 2012; Mathe-Souleka, et al., 2015; Namin, 2017). Sahagun \& Vasquez-Parraga (2014) argued that food quality could be less important towards customer satisfaction. But this condition only exists if the fast-food customers were satisfied with the service given. The result of this study proves the opposite, as both the food quality and service quality do not significantly affect customer satisfaction.

Food quality becomes relevant however, when direct testing of quality is performed towards customer loyalty. This shows that general fast-food customers are not influence by food quality to be satisfied by a fast-food product. But, when they find a fast-food product with a good food quality that they like, they become loyal to this product.

Although food quality, service quality, and environment, according to the result of this study do not contribute towards customer loyalty through customer satisfaction, it is suspected that there is a minimum level of quality that the customers expected a fast-food shop to have. Considering the price level of fast-food product, customers may not require these qualities to be good, but they also do not want these qualities to be bad. Although seems logical, a different study is needed to confirm this notion.

In a low-switching cost environment, it is always expected that price plays a large part in defining customer satisfaction (Stango, 2002; Tsai, et al., 2010). The same thing also happens in the local fast-food industry in Indonesia. This finding is also supported by many other studies regarding customer satisfaction and customer loyalty in fast-food industry (Kim, et al., 2006; Law, et al., 2008; Han \& Ryu, 2009; Haghighi, 2012; Jin, et al., 2012; Voon, 2017). Price still plays a significant part in affecting customer loyalty when direct testing is performed. This means that price is a very important feature that has to be prioritized by local fast-food industry in Indonesia.

Location is proven to have a significant effect towards customer loyalty, through customer satisfaction. This finding is also supported by many other studies (Soriano, 2002; Tzeng, et al., 2002; Hyun, 2010; Haghighi, 2012). However, contrary to food quality, location becomes insignificant when direct testing is performed. These interesting findings could mean that local fast-food customers have the tendency to become 
loyal if they find a fast-food product with good quality, even if the location is not that strategic. But to be satisfied, local fast-food customers require the location to be in a strategic place, regardless of the food quality. It would be interesting if this notion could be confirmed in a further study with a greater detail regarding relationship exclusively among customer loyalty, customer satisfaction, food quality, and location.

Lastly, the result shows that the mediating effect from customer satisfaction is not significant after all. Both with and without customer satisfaction there are 2 factors that influence customer loyalty. Price is always important whether customer satisfaction is considered or not. Low-switching cost factor in this industry influence the customers to prioritize price more than the other factors. Food quality and location however, show that there are 2 options for firms in the local fast-food industry to gain customer loyalty. The first is by using food quality to directly gain customer loyalty. Regardless of the location, this study shows that customers who like a fastfood product will be loyal and actively looking for it. However, if a firm is not able to produce superior fastfood product with good quality, it can always try the second option with location. Having a good location proves to be a defining factor to make customers satisfy. But this option is more difficult because to ultimately lead to customer loyalty, customer satisfaction has to be nurtured first. So, the choice is on the firm regarding customer loyalty. Providing a good recipe is hard, but it leads directly to customer loyalty. Picking a better location can be relatively easier but it does not directly end up in customer loyalty, which makes keeping customers loyal to be harder.

\section{Conclusion}

The SEM result of this study confirms that local fast-food industry in Indonesia is different. It is shown by the fact that among all of the factors considered, only price and location affect customer loyalty through customer satisfaction while food quality, service quality, and environment do not. This result is against the majority of studies regarding customer satisfaction and customer loyalty in the fast-food industry.

Direct testing of quality attributes towards customer loyalty without mediating effect from customer satisfaction provide a different result. Price still significantly affects customer loyalty without the presence of customer satisfaction which makes it the only quality attributes that affect customer loyalty in both scenarios. However, location becomes insignificant in the direct testing. Food quality becomes significantly affecting customer loyalty instead, in place of location.

Another importance of this study comes from the fact that local fast-food industry consists of small medium enterprises (SMEs) which usually have little to no budget to perform research. As far as this study is concerned, application of studies of marketing in SMEs, especially in Indonesia, is very rare. Furthermore, even if players in the local fast-food industry tries to implement some of the results of previous studies, they will still come up short. This study has shown that results of previous studies regarding fast-food industry are not compatible with the nature of local fast-food industry in Indonesia.

Understandably, this study still has few limitations. First, population of study is only taken from 1 local fast-food shop in Bandung, so generalizability can still be improved in further study by including more fastfood shop in different areas. Second, although this study includes relatively more variables compared to other similar studies, there are still other product/service quality variables can still be considered in further study such as food safety that might have a significant effect towards customer satisfaction as well as customer loyalty. This study also provides many interesting findings which could used as the background for further studies in the future.

\section{References}

Alhelalat, J. A., Habiballaha, M. A., \& Twaissi, N. M. (2017). The impact of personal and functional aspects of restaurant employee service behaviour on customer satisfaction. International Journal of Hospitality Management, 66, 46-53.

Alshurideh, M. T. (2016). Is customer retention beneficial for customers: A conceptual background. Journal of Research in Marketing, 5(3), 382-389.

Andaleeb, S., \& Conway, C. (2006). Customer satisfaction in the restaurant industry: an examination of the transaction-specific model. Journal of services marketing, 20(1), 3-11.

Baker, D., \& Crompton, J. L. (2000). Quality, satisfaction and behavioral intentions. Annals of Tourism Research, 27(3), 785-804.

Canny, I. U. (2014). Measuring the Mediating Role of Dining Experience Attributes on Customer Satisfaction and Its Impact on Behavioral Intentions of Casual Dining Restaurant in Jakarta. International Journal of Innovation, Management and Technology, 5(1), 25-29.

Cronin, J. J., \& Taylor, S. A. (1992). Measuring Service Quality: A Reexamination and Extension. Journal of Marketing, 56(3), 56-68.

Doganoglu, T. (2010). Switching costs, experience goods and dynamic price competition. $Q M E, 8(2), 167-$ 205.

Etemad-Sajadi, R., \& Rizzuto, D. (2013). The Antecedents of Consumer Satisfaction and Loyalty in Fast Food Industry. International Journal of Quality and Reliability Management, 30(7), 780-798. 
González, M. E. A., Comesaña, L. R., \& Brea, J. A. F. (2007). Assessing tourist behavioral intentions through perceived service quality and customer satisfaction. Journal of business research, 60(2), 153-160.

Grunert, K. (2005). Food quality and safety: consumer perception and demand. European Review of Agricultural Economics, 32(3), 369-391.

Haghighi, M., Dorosti, A., Rahnama, A., \& Hoseinpour, A. (2012). Evaluation of factors affecting customer loyalty in the restaurant industry. African Journal of Business Management, 6(14), 5039-5046.

Han, H., \& Ryu, K. (2009). The roles of the physical environment, price perception, and customer satisfaction in determining customer loyalty in the restaurant industry. Journal of hospitality \& tourism research, 33(4), 487-510.

Hair, J. F., Black, W. C., Babin, B. J., \& Anderson, R. E. (2014). Multivariate Data Analysis 7th. Harlow: Pearson Educated Ltd.

Heung, V. C. (2002). American theme restaurants: A study of consumer's perceptions of the important attributes in restaurant selection. Asia Pacific Journal of Tourism Research, 7(1), 19-28.

Hyun, S. S. (2010). Predictors of relationship quality and loyalty in the chain restaurant industry. Cornell Hospitality Quarterly, 51(2), 251-267.

Jin, N., Lee, S., \& Huffman, L. (2012). Impact of restaurant experience on brand image and customer loyalty: Moderating role of dining motivation. Journal of Travel \& Tourism Marketing, 29(6), 532-551.

Kim, W. G., Lee, Y. K., \& Yoo, Y. J. (2006). Predictors of relationship quality and relationship outcomes in luxury restaurants. Journal of Hospitality \& Tourism Research, 30(2), 143-169.

Law, R., To, T., \& Goh, C. (2008). How do Mainland Chinese travelers choose restaurants in Hong Kong?: An exploratory study of individual visit scheme travelers and packaged travelers. International Journal of Hospitality Management, 27(3), 346-354.

Lee, J., Lee, J., \& Feick, L. (2001). The impact of switching costs on the customer satisfactionloyalty link: mobile phone service in France. Journal of services marketing, 15(1), 3548.

Liu, W.-K., Lee, Y.-S., \& Hung, L.-M. (2016). The interrelationships among service quality, customer satisfaction, and customer loyalty: Examination of the fast-food industry. Journal of Foodservice Business Research, 20(2), 146-162.

Mason, K., Jones, S., Benefield, M., \& Walton, J. (2016). Building Consumer Relationship in the Quick
Service Restaurant Industry. Journal of Foodservice Business Research, 19(4), 368-381.

Mathe-Soulek, K., Slevitch, L., \& Dallinger, I. (2015). Applying mixed methods to identify what drives quick service restaurant's customer satisfaction at the unit-level. International Journal of Hospitality Management, 50, 46-54.

Namin, A. (2017). Revisiting Customers' Perception of Service Quality in Fast Food Restaurants. Journal of Retailing and Consumer Services, 34, 70-81.

Namkung, Y., \& Jang, S. (2007). Does Food Quality Really Matter in Restaurants? Its Impact On Customer Satisfaction And Behavioral Intentions. Journal of Hospitality \& Tourism Research, 31(3), 387-410.

Oliver, R. L. (1999). Whence Consumer Loyalty? Journal of Marketing 63, Fundamental Issues and Directions for Marketing, 33-44.

Parasuraman, A., Zeithaml, V., \& Berry, L. (1988). SERVQUAL: A multiple- Item Scale for measuring consumer perceptions of service quality. Journal of Retailing, 64, 12-39.

Qin, H., Prybutok, V. R., \& Zhao, Q. (2010). Perceived service quality in fast-food restaurants: empirical evidence from China. International Journal of Quality \& Reliability Management, 27(4), 424437.

Reichheld, F. (1996). The Loyalty Effect. Boston: Harvard Business Press.

Rijswijk, W., \& Frewer, L. (2008). Consumer perceptions of food quality and safety and their relation to traceability. British Food Journal, 110(10), 10341046.

Ryu, K., \& Han, H. (2010). Influence of the Quality of Food, Service, and Physical Environment on Customer Satisfaction and Behavioral Intention in Quick-Casual Restaurants: Moderating Role of Perceived Price. Journal of Hospitality and Tourism Research, 34(3), 310-329.

Sahagun, M. A., \& Vasquez-Parraga, A. Z. (2014). Can fast-food Consumers be Loyal Customers, if So How? Theory, Method and Findings. Journal of Retailing and Consumer Services, 21, 168-174.

Stango, V. (2002). Pricing with consumer switching costs: Evidence from the credit card market. The Journal of Industrial Economics, 50(4), 475-492.

Soriano, D. (2002). Customers' expectations factors in restaurants: The situation in Spain. International Journal of Quality \& Reliability Management, 19(8/9), 1055-1067.

Stevens, P., Knutson, B., \& Patton, M. (1995). Dineserv: A Tool for Measuring Service Quality in Restaurants. Cornell Hotel and Restaurant Administration Quarterly, 36(2), 36-56. 
Terblanche, N. S. (2009). Do Quality, Value, Satisfaction and Loyalty Differ Amongst Different Cultural Groups of KFC Customers? ANZMAC.

Tsai, M. T., Tsai, C. L., \& Chang, H. C. (2010). The effect of customer value, customer satisfaction, and switching costs on customer loyalty: An empirical study of hypermarkets in Taiwan. Social Behavior and Personality: an international journal, 38(6), 729-740.

Tzeng, G. H., Teng, M. H., Chen, J. J., \& Opricovic, S. (2002). Multicriteria selection for a restaurant location in Taipei. International journal of hospitality management, 21(2), 171-187.
Voon, B. H. (2017). Service Environment of Restaurants: Findings from the youth customers. Journal of ASIAN Behavioural Studies, 2(2), 67-77.

Wijanto S. H. (2008). Structural Equation Modelling with LISREL 8.8. Yogyakarta: Graha Ilmu.

Wu, C. H. J., \& Liang, R. D. (2009). Effect of experiential value on customer satisfaction with service encounters in luxury-hotel restaurants. International Journal of Hospitality Management, 28(4), 586-593. 